\title{
Upaya Meningkatkan Budaya Disiplin Guru dalam Kehadiran Mengajar Melalui Penerapan Reward and Punishment di SD Negeri Aik Kangkung Kecamatan Sekongkang Kabupaten Sumbawa Barat
}

\author{
Saharuddin, S.Pd., M.M \\ email:sahaja.dj@gmail.com
}

\begin{abstract}
Abstrak: Tujuan Penelitian ini adalah untuk meningkatkan budaya disiplin guru dalam kehadiran mengajar di kelas melalui reward and punishment di SDN Aik Kangkung Kecamatan Sekongkang. Dalam Penelitian Tindakan Sekolah (PTS) ini, dicobakan tindakan berupa penerapan Reward and Punishment untuk para guru di SDN Aik Kangkung Kecamatan Sekongkang. Penelitian ini dilaksanakan dalam dua siklus. Hasil penelitian pada siklus 1 kedisiplinan kehadiran guru dalam mengajar di kelas terlambat kurang dari 5 menit mencapai 37,5\% sehingga belum memenuhi indikator yang telah ditetapkan sebesar 75\%. Pada siklus kedua kedisiplinan kehadiran guru dalam mengajar di kelas terlambat kurang dari 5 menit mencapai hasil 87,5\%, dari hasil penelitian dan analisa data, pada siklus kedua, kedisiplinan kehadiran guru dikelas pada proses pembelajaran meningkat dan memenuhi indikator yang telah ditetapkan sebesar 75\%. Dapat disimpulkan bahwa untuk meningkatkan kedisiplinan kehadiran guru dikelas pada kegiatan pembelajaran dapat dilakukan dengan penerapan Reward and Punishment kepada guru.
\end{abstract}

Kata Kunci : Budaya, Disiplin Guru, Reward and Punishment

\section{Pendahuluan}

A. Latar belakang

Untuk meningkatkan peranan guru dalam proses belajar mengajar dan hasil belajar siswa, maka diharapkan guru mampu menciptakan lingkungan belajar yang efektif dan akan mampu mengelola kelas dengan baik. Guru adalah pendidik profesional dengan tugas utama mendidik dan mengevaluasi peserta didik, pada pendidikan anak usia dini jalur pendidikan formal, pendidikan dasar dan pendidikan menengah. Dalam informasi tentang wawasan Wiyatamandala, kedisiplinan guru diartikan sebagai sikap mental yang mengandung kerelaan mematuhi semua ketentuan, peraturan dan norma yang berlaku dalam menunaikan tugas dan tangung jawab.

Dari pengertian diatas dapat disimpulkan, kedisiplinan guru dan pegawai adalah sikap penuh kerelaan dalam mematuhi semua aturan dan norma yang ada dalam menjalankan tugasnya sebagai bentuk tanggung jawabnya terhadap pendidikan anak didiknya. Karena bagaimana pun 
seorang guru atau tenaga kependidikan (pegawai), merupakan cermin bagi anak didiknya dalam sikap atau teladan.Dari sikap disiplin guru dan tenaga kependidikan (pegawai) akan memberikan warna terhadap hasil pendidikan yang jauh lebih baik. Upaya lain yang dapat dilakukan untuk meningkatkan kedisiplinan guru dalam kehadirannya di kelas adalah dengan menerapkan reward dan punishment. Elizabeth B. Hurlock memposisikan reward dan punishment sebagai salah satu pilar dari disiplin, menurutnya reward berarti tiap bentuk penghargaan untuk suatu hasil yang baik, penghargaan tidak perlu berbentuk materi, tetapi berupa kata-kata pujian, senyuman atau tepukan di punggung (Hurlock, 1990:90).

Keberhasilan proses pembelajaran sangat bergantung pada beberapa faktor diantaranya adalah faktor guru. Guru sangat memegang peranan penting dalam keberhasilan proses pembelajaran. Guru yang mempunyai kompetensi yang baik tentunya akan sangat mendukung keberhasilan proses pembelajaran (Mulyasa,2009).

Keteladanan guru dapat dilihat dari prilaku guru sehari-hari baik didalam sekolah maupun diluar sekolah. Selain keteladanan guru, kedisiplinan guru juga menjadi salah satu hal penting yang harus dimiliki oleh guru sebagai seorang pengajar dan pendidik. Fakta dilapangan yang sering kita jumpai disekolah adalah kurang disiplinnya guru, terutama masalah disiplin guru masuk kedalam kelas pada saat kegiatan pembelajaran dikelas.

Berdasarkan uraian diatas, penulis tertarik untuk melakukan penelitian tindakan sekolah dengan judul : "Usaha Meningkatkan Budaya Disiplin Guru dalam Kehadiran Mengajar Dikelas Melalui penerapan Reward and Punishment di SD Negeri Aik Kangkung.Berdasarkan pengalaman penulis,dari sekian sekolah yang pernah penulis bertugas dapat melihat persamaan kebiasan dari bapak/ ibu guru yang kurang disiplin waktu masuk kelas pada saat mulainya proses pembelajaran di kelas dan setelah waktu istirahat.Fenomena yang sama ini berlanjut lagi pada sekolah dimana peneliti tempat tugas sekarang ini.Selaku Kepala yang baru,memilki keinginan yang kuat untuk merubah kebiasaan-kebiasaan yang menurut peneliti tidak positip atau kurang bagus,justru akan berdampak pada prestasi hasil belajar siswa.Untuk itu judul yang peneliti angkat merupakan salah langkah dalam upaya untuk menghilangkan kebiasaan yang menurut peneliti kurang bagus.

\section{B. Identifikasi Masalah}

Masalah-masalah yang mendasari dari penelitian ini adalah :

1. Masih banyak guru yang datang terlambat ke sekolah.

2. Masih kurangnya disiplin guru dalam kehadiran mengajar dikelas.

3. Guru masih sering terlambat masuk kelas.

4. Masih ada guru yang kurang menghargai waktu.

5. Masih melekatnya budaya bercerita di ruang guru atau di luar kelas setelah waktu masuk kelas 


\section{Pembatasan Masalah}

Penelitian ini dibatasi pada upaya meningkatkan budaya disiplin guru dalam kehadiran mengajar dikelas melalui penerapan Reward and Punishment.

\section{Rumusan Masalah}

Rumusan masalah dalam penelitian ini adalah : "Apakah penerapan Reward and Punishment dapat meningkatkan budaya kedisiplinan guru dalam kehadiran mengajar dikelas?"

\section{E. Tujuan Penelitian}

Tujuan dari penelitian ini adalah ingin mencari alternatif pemecahan masalah sebagai upaya meningkatkan budaya disiplin guru dalam kehadiran mengajar dikelas melalui penerapan Reward and Punishment.

\section{F. Manfaat Penelitian}

Penelitian ini diharapkan dapat bermanfaat, sbb :

1. Bagi kepala sekolah adalah merupakan wujud nyata kepala sekolah dalam memecahkan berbagai masalah disekolah melalui kegiatan penelitian.

2. Bagi guru diharapkan dapat menjadi motivasi guru dalam meningkatkan kedisiplinan dalam kehadiran.

3. Bagi sekolah bisa dijadikan sumbangan dalam mewujudkan budaya sekolah yang dapat mendorong keberhasilan dan peningkatan mutu pembelajaran.

\section{G. Definisi Istilah}

Secara umum budaya adalah suatu cara hidup yang terdapat pada sekelompok manusia yang berkembang dan diwariskan secara turun temurun dari generasi ke generasi berikutnya. Budaya sekolah adalah nilainilai dominan yang didukung oleh sekolah atau falsafah yang menuntun kebijakan sekolah terhadap semua unsur dan komponen sekolah termasuk stakeholders pendidikan, seperti cara melaksanakan pekerjaan di sekolah serta asumsi atau kepercayaan dasar yang dianut oleh personil sekolah. Budaya sekolah merujuk pada suatu sistem nilai, kepercayaan dan normanorma yang diterima secara bersama, serta dilaksanakan dengan penuh kesadaran sebagai perilaku alami, yang dibentuk oleh lingkungan yang menciptakan pemahaman yang sama diantara seluruh unsur dan personil sekolah baik itu kepala sekolah, guru, staf, siswa dan jika perlu membentuk opini masyarakat yang sama dengan sekolah. (Akhmad Sudrajat, 2010).

Disiplin berasal dari bahasa latin Discere yang berarti belajar. Dari kata ini timbul kata Disciplina yang berarti pengajaran atau pelatihan. Dan sekarang kata disiplin mengalami perkembangan makna dalam beberapa pengertian. Pertama, disiplin diartikan sebagai kepatuhan terhadap peratuaran atau tunduk pada pengawasan, dan pengendalian. Kedua disiplin sebagai latihan yang bertujuan mengembangkan diri agar dapat berperilaku tertib. Menurut Kamus Bahasa Indonesia, disiplin adalah ketaatan pada 
peraturan (tata tertib). Dalam penelitian ini, disiplin dibatasi hanya pada kehadiran guru dikelas pada kegiatan belajar mengajar.

Guru adalah pendidik profesional dengan tugas utama mendidik, mengajar, membimbing, mengarahkan, melatih, menilai, dan mengevaluasi peserta didik pada pendidikan anak usia dini jalur pendidikan formal, pendidikan dasar,dan pendidikan menengah. (UU No. 14, Tahun 2005)

Reward and Punisment diartikan sebagai pemberian penghargaan dan hukuman, penghargaan disini bukan hanya penghargan dalam bentuk materi saja termasuk didalamnya adalah pujian kepada guru yang dipandang disiplin dalam kehadiran dikelas pada kegiatan belajar mengajar dan teguran atau hukuman kepada guru yang sering terlambat masuk kelas.

\section{Kajian Pustaka}

\section{A. Deskripsi Sekolah}

SD Negeri Aik Kangkung adalah merupakan salah satu Sekolah Dasar Negeri yang berada di wilayah pemukiman Transmigrasi atau sering dikenal dengan istlah Satuan Pemukimn satu (SP1) Desa Ai' Kangkung yang masuk dalam wilayah administrasi Kecamatan Sekongkang Kabupaten Sumbawa Barat yang terletak di bagian selatan Ibu kota Kabupaten Sumabawa Barat.SD Negeri Aik Kangkung mempunyai hawa yang sejuk dan pemandangan yang indah karena lokasinya termasuk dalam salah satu zona Wisata Pantai yang ada Kabupaten Sumbawa Barat,dimana jarak dari sekolah ke Pantai $\pm 1 \mathrm{Km}$

Jarak sekolah dari Ibu Kota Kabupaten, lebih kurang adalah $65 \mathrm{Km}$, dan jarak dari Ibu Kota Kecamatan, lebih kurang $10 \mathrm{~km}$. Sekolah ini berdiri pada tahun 1995. Jumlah tenaga pendidik dan tenaga kependidikan sekarang sebanyak 10 Orang,yang terdiri dari 6 guru kelas 2 guru mata pelajaran dan 1orang tenaga kependidikan serta ditambah dengan seorang kepala sekplah dengan jumlah siswa sebanyak 142 orang.

\section{B. Kajian Teori}

Berbagai penelitian menunjukkan peran kunci yang dapat dilakukan kepala sekolah agar dapat meningkatkan belajar dan pembelajaran, jelas bahwa kepala sekolah harus berperan sebagai leaders for learning (The Institute for Educational Leadership, 2000). Para kepala sekolah harus mengetahui isi pelajaran dan teknik teknik pedagogis. Para kepala sekolah harus bekerja bersama guru untuk meningkatkan keterampilan. Kepala sekolah harus mengumpulkan, menganalisis, dan menggunakan data dengan cara-cara yang menumbuhkan keunggulan. Mereka harus bisa membaur dengan siswa, guru, orang tua, organisasi-organisasi layanan sosial dan kesehatan.

Prinsip transpransi dan akuntabilitas yang terus memberikan warna dalam peningkatan mutu pendidikan.Seiring dengan perkembangan ilmu pengetahuan dan teknologi,yang dikenal dengan istilah Revolusi Industri 4.0 yang dapat mempengaruhi segala sisi kehidupan manusia.

Pendidikan bukan hanya menyampaikan keterampilan yang sudah dikenal, namun harus dapat meramalkan berbagai jenis keterampilan dan kemahiran yang akan datang, dan sekaligus menemukan cara yang tepat dan 
cepat dikuasai oleh anak didik.(Budiningsih,2005).Kedudukan guru dipahami demikian penting sebagai ujung tombak dalam pembelajaran dan pencapaian mutu hasil belajar peserta didik (Sagala, 2003).

Budaya sekolah merujuk pada suatu sistem nilai, kepercayaan dan norma-norma yang diterima secara bersama, serta dilaksanakan dengan penuh kesadaran sebagai perilaku alami, yang dibentuk oleh lingkungan yang menciptakan pemahaman yang sama diantara seluruh unsur dan personil sekolah baik itu kepala sekolah, guru, staf, siswa dan jika perlu membentuk opini masyarakat yang sama dengan sekolah. (Akhmad Sudrajat, 2010).

Beberapa manfaat yang bisa diambil dari upaya pengembangan budaya sekolah, diantaranya : (1) menjamin kualitas kerja yang lebih baik; (2) membuka seluruh jaringan komunikasi dari segala jenis dan level baik komunikasi vertikal maupun horisontal; (3) lebih terbuka dan transparan; (4) menciptakan kebersamaan dan rasa saling memiliki yang tinggi; (4) meningkatkan solidaritas dan rasa kekeluargaan; (5) jika menemukan kesalahan akan segera dapat diperbaiki; dan (6) dapat beradaptasi dengan baik terhadap perkembangan IPTEK. Selain beberapa manfaat di atas, manfaat lain bagi individu (pribadi) dan kelompok adalah : (1) meningkatkan kepuasan kerja; (2) pergaulan lebih akrab; (3) disiplin meningkat; (4) pengawasan fungsional bisa lebih ringan; (5) muncul keinginan untuk selalu ingin berbuat proaktif; (6) belajar dan berprestasi terus serta; dan (7) selalu ingin memberikan yang terbaik bagi sekolah, keluarga, orang lain dan diri sendiri.

Upaya pengembangan budaya sekolah seyogyanya mengacu kepada beberapa prinsip berikut ini.yaitu:Berfokus pada Visi, Misi dan Tujuan Sekolah,Penciptaan Komunikasi Formal dan Informal,

Inovatif dan Bersedia Mengambil Resiko,Memiliki Strategi yang jelas,Berorientasi Kinerja, Sistem Evaluasi yang Jelas, Memiliki Komitmen yang Kuat, Keputusan Berdasarkan Konsensus, Sistem Imbalan yang jelas,dan Evaluasi Diri upaya pengembangan budaya sekolah juga seyogyanya berpegang pada asas-asas berikut ini : Kerjasama tim (teamwork), Kemampuan, Keinginan, Kegembiraan, Hormat , Jujur dan Disiplin

Menurut Ekosiswoyo dan Rachman (2000), kedisiplinan adalah sekumpulan tingkah laku individu maupun masyarakat yang mencerminkan rasa ketaatan, kepatuhan, yang didukung oleh kesadaran untuk menunaikan tugas dan kewajiban dalam rangka pencapaian tujuan

Reward dan punishment merupakan dua bentuk metode dalam memotivasi seseorang untuk melakukan kebaikan dan meningkatkan prestasinya. Kedua metode ini sudah cukup lama dikenal dalam dunia kerja. Tidak hanya dalam dunia kerja, dalam dunia penidikan pun kedua ini kerap kali digunakan. Namun selalu terjadi perbedaan pandangan, mana yang lebih diprioritaskan antara reward dengan punishment?

Reward artinya ganjaran, hadiah, penghargaan atau imbalan. Dalam konsep manajemen, reward merupakan salah satu alat untuk peningkatan motivasi para pegawai. Metode ini bisa meng-asosiasi-kan perbuatan dan kelakuan seseorang dengan perasaan bahagia, senang, dan biasanya akan membuat mereka melakukan suatu perbuatan yang baik secara berulang- 
ulang. Selain motivasi, reward juga bertujuan agar seseorang menjadi giat lagi usahanya untuk memperbaiki atau meningkatkan prestasi yang telah dapat dicapainya.

Sementara punishment diartikan sebagai hukuman atau sanksi. Jika reward merupakan bentuk reinforcement yang positif; maka punishment sebagai bentuk reinforcement yang negatif, tetapi kalau diberikan secara tepat dan bijak bisa menjadi alat motivasi. Tujuan dari metode ini adalah menimbulkan rasa tidak senang pada seseorang supaya mereka jangan membuat sesuatu yang jahat. Jadi, hukuman yang dilakukan mesti bersifat pedagogies, yaitu untuk memperbaiki dan mendidik ke arah yang lebih baik.

\section{Metodelogi Penelitian}

\section{A. Pentahapan Penelitian Tindakan}

Metode yang digunakan dalam penelitian ini adalah metode Penelitian Tindakan Sekolah (PTS). PTS merupakan suatu prosedur penelitian yang diadaptasi dari Penelitian Tindakan Kelas (PTK) (Panitia Pelaksana Pendidikan dan Latihan Profesi Guru Rayon 10 Jawa Barat, 2009 : 73). Penelitian tindakan sekolah merupakan "(1) penelitian partisipatoris yang menekankan pada tindakan dan refleksi berdasarkan pertimbangan rasional dan logis untuk melakukan perbaikan terhadap suatu kondisi nyata; (2) memperdalam pemahaman terhadap tindakan yang dilakukan; dan (3) memperbaiki situasi dan kondisi sekolah / pembelajaran secara praktis" (Depdiknas, 2008 : 11-12). Secara singkat, PTS bertujuan untuk mencari pemecahan permasalahan nyata yang terjadi di sekolah-sekolah, sekaligus mencari jawaban ilmiah bagaimana masalah-masalah tersebut bisa dipecahkan melalui suatu tindakan perbaikan.

Pendekatan yang digunakan dalam penelitian tindakan ini ialah pendekatan kualitatif. Artinya, penelitian ini dilakukan karena ditemukan permasalahan rendahnya tingkat kedisiplinan guru dalam kehadiran dikelas pada proses kegiatan belajar mengajar. Permasalahan ini ditindaklanjuti dengan cara menerapkan sebuah model pembinaan kepada guru berupa penerapan Reward dan Punishment yang dilakukan oleh kepala sekolah, kegiatan tersebut diamati kemudian dianalisis dan direfleksi. Hasil revisi kemudian diterapkan kembali pada siklus-siklus berikutnya.

Penelitian ini adalah penelitian tindakan model Stephen Kemmis dan Mc. Taggart (1998) yang diadopsi oleh Suranto (2000; 49) yang kemudian diadaptasikan dalam penelitian ini. Model ini menggunakan sistem spiral refleksi diri yang dimulai dari rencana, tindakan, pengamatan, refleksi, dan perencanaan kembali yang merupakan dasar untuk suatu ancang-ancang pemecahan masalah. Seperti yang diungkapkan oleh Mills $(200 ; 17)$ "Stephen Kemmis has created a well known representation of the action research spiral ..... Peneliti menggunakan model ini karena dianggap paling praktis dan aktual.

Kegiatan penelitian tindakan sekolah ini, terdiri atas beberapa tahap, yaitu: Perencanaan,Pelaksanaan,Pengamatan,dan Refleksi 


\section{B. Lokasi dan Waktu Penelitian}

1. Lokasi Penelitian : SD Negeri Aik Kangkung

2. Waktu Penelitian : 1 Februari 2019 s.d. 30 Maret 2019

\section{Subjek Penelitian}

Yang menjadi subjek penelitian tindakan sekolah ini adalah guru-guru di SD Negeri Aik Kangkung Kecamatan Sekongkang Kabupaten Sumbawa Barat, sejumlah 8 orang guru, terdiri atas 6 orang guru kelas ,1 orang guru Pendidikan Agama Islam dan 1 orang guru Pendidikan Jasmani Olah raga dan Kesehatan.

\section{Tindakan}

Tindakan yang dilakukan dalam penelitian ini adalah pemberian reward dan punishment kepada guru mengenai kedisiplinan guru dalam kehadiran dikelas dalam proses pembelajaran oleh kepala sekolah. Diharapkan dengan pemberian reward dan punishment yang diberikan oleh kepala sekolah akan terjadi perubahan atau peningkatan kedisiplinan guru dalam kehadiran dikelas dalam proses pembelajaran.

Karena keterbatasan waktu, penelitian tindakan sekolah ini hanya dilaksanakan sebanyak dua siklus. Masing-masing siklus dilaksanakan selama satu bulan.

\section{E. Teknik Pengumpulan Data}

Teknik pengumpulan data dari penelitian tindakan sekolah ini adalah melalui data kualitatif yang diperoleh dari observasi, pengamatan, maupun wawancara.

1. Wawancara

Teknik ini digunakan untuk mendapatkan data dari informan secara langsung. Dalam melakukan wawancara dipergunakan pedoman wawancara yang terbuka.

2. Pengumpulan data sekunder

Teknik ini digunakan untuk mengumpul data sekunder melalui dokumen-dokumen tertulis yang diyakini integritasnya karena mengambil dari berbagai sumber yang relevan dengan penelitian. Pengambilan sumber yang bersifat sekunder ini dapat diperoleh dari hasil dialog bersama kolaborator, data base sekolah, dan lain-lain.

3. Observasi atau pengamatan

Observasi digunakan untuk melengkapi data dari wawancara dan pengumpulan dokumentasi, terutama dalam lingkup masalah penelitian, antara lain mengamati impelementasi kebijakan yang berkaitan dengan kedisiplinan guru dalam kehadiran dikelas pada kegiatan belajar mengajar.

\section{F. Instrumen Penelitian}

Instrumen penelitian yang digunakan dalam penelitian tindakan sekolah ini antara lain adalah :Skala Penilaian,Lembar pengamatan,dan daftar wawancara 


\section{G. Teknik Analisis Data}

Analisa data yang digunakan dalam penelitian ini adalah analisa data kualitatif yang bersumber dari data primer maupun empiris. Melalui analisa data ini, dapat diketahui ada tidaknya peningkatan budaya kedisiplinan guru dalam kehadiran dikelas melalui pemberian reward dan punishment yang merupakan fokus dari penelitian tindakan sekolah ini.

\section{Hasil Penelitian dan Pembahasan}

Penelitian Tindakan Sekolah (PTS) ini dilaksanakan dalam dua siklus. Hali ini dikarenakan keterbatasan waktu yang tersedia, serta dengan dua siklus sudah penulis anggap cukup untuk peningkatan disiplin guru dalam kehadiran dikelas pada kegiatan belajar mengajar.

Secara umum kegiatan penelitian tindakan sekolah pada siklus 1 dan siklus 2 sama terdiri atas beberapa tahap, yaitu : perencanaan, pelaksanaan, pengamatan dan refleksi. Bedanya pada siklus 2 merupakan penyempurnaan dari kegiatan pada siklus 1 setelah refleksi. Kekurangan-kekurangan atau hambatan pada siklus 1 sempurnakan atau ditindaklanjuti pada siklus 2 .

\section{A. Siklus 1}

Siklus 1 terdiri atas beberapa tahap, yaitu : (1) Perencanaan, (2) Pelaksanaan, (3) Pengamatan dan Evaluasi, dan (4) Refleksi.

\section{Perencanaan}

Perencanaan adalah langkah awal yang dilakukan oleh penulis saat akan memulai tindakan. Agar perencanaan mudah dipahami dan dilaksanakan oleh penulis yang akan melakukan tindakan, maka penulis membuat rencana tindakan sebagai berikut :

a. Merumusan masalah yang akan dicari solusinya. Dalam penelitian ini masalah yang akan dicari solusinya adalah masih banyaknya guru yang kurang disiplin dalam kehadiran dikelas pada proses belajar mengajar.

b. Merumusan tujuan penyelesaian masalah/tujuan menghadapi tantangan/tujuan melakukan inovasi/tindakan. Dalam penelitian ini penulis mengambil rencana untuk melakukan tindakan memberikan Reward dan Punishment kepada guru- guru untuk meningkatkan kedisiplinan guru dalam kehadiran dikelas pada proses belajar mengajar.Merumusan indikator keberhasilan penerapan Reward dan Punishment dalam meningkatkan budaya disiplin guru dalam kehadiran dikelas pada proses belajar mengajar. Indikator keberhasilan penerapan tindakan ini penulis tetapkan sebesar 75\%, artinya tindakan ini dinyatakan berhasil bila $75 \%$ guru tidak terlambat masuk kelas dalam proses pembelajaran.

c. Merumusan langkah-langkah kegiatan penyelesaian masalah/ kegiatan menghadapi tantangan/ kegiatan melakukan tindakan.

Langkah-langkah yang diambil penulis dalam melakukan tindakan antara lain adalah melakukan sosialisasi kepada para guru 
mengenai penelitian yang akan dilaksanakan, serta menyampaikan tujuan dari penerapan tindakan yang dilakukan oleh penulis.

Kepada para guru disampaikan mengenai penerapan Reward dan Punishment yang akan diterapkan dalam penelitian ini. Pada siklus pertama ini, akan dipampang/ ditempel diruang guru, maupun diruang TU, peringkat nama-nama guru yang paling rendah tingkat keterlambatan masuk kelasnya sampai yang paling tinggi tingkat keterlambatannya.

d. Mengidentifikasi warga sekolah dan atau pihak-pihak terkait lainnya yang terlibat dalam penyelesaian masalah/menghadapi tantangan/melakukan tindakan. Penulis melakukan identifikasi siapa saja yang dilibatkan dalam penelitian ini. Pihak-pihak yang dilibatkan dalam penelitian ini adalah : guru, guru piket, staf tata usaha,tenaga tidak tetap,siswa dan masyrakat sekitar sekolah.

e. Mengidentifikasi metode pengumpulan data yang akan digunakan.

Metode pengumpulan data yang diambil oleh penulis merupakan data kualitatif melalui observasi, pengamatan serta wawancara kepada siswa,staf tata usaha,tenaga tidak tetap bahkan masyarakat untuk mengetahui tingkat kehadiran guru di sekolah dan dikelas pada kegiatan belajar mengajar.

f. Penyusunan instrumen pengamatan dan evaluasi.

Dalam pengambilan data, penulis menggunakan instrument berupa lembar observasi/pengamatan, skala penilaian serta daftar dokumen wawancara yang dapat ditanyakan kepada staf tata usaha,pegawai tidak tetap,siswa,ataupun masyarakat sekitar sekolah untuk mengetahui tingkat kehadiran guru di sekolah dan di kelas dalam proses kegiatan belajar mengajar.

g. Mengidenifikasi fasilitas yang diperlukan.

Fasilitas atau alat bantu yang digunakan dalam penelitian ini antara lain : kertas (lembar pengamatan), alat tulis berupa balpoin, serta jam dinding yang ada disetiap kelas, serta rekap jumlah kehadiran dari setiap guru.

h. Bentuk Reward dan Punishment yang digunakan seperti memberikan piagam penghargaan bagi guru yang masuk kelas kurang dari 5 menit dengan sebutan sangat baik,bagi guru yang masuk kelas antara 5 - 10 menit dengan sebutan baik,dan guru yang masuk kelas lebih dari 10 menit sebutannya cukup.Piagam penghargaan ini dikeluarkan oleh kepala sekolah dan diketahui oleh Kepala Dinas Pendidikan Pemuda dan Olahraga sebagai bentuk Penghargaan terhadap guru yang telah disiplin waktu melaksanakan tugasnya.Piagam penghargaan tersebut dapat digunakan sebagai unsur penunjang dalam angka kredit jabatan guru.

2. Pelaksanaan

Pelaksanaan penelitian tindakan sekolah ini dilaksanakan melalui beberapa kegiatan, antara lain :

a. Pada siklus 1 ini,peneliti sendiri yang lebih dominan melakukan 
pengamatan/ observasi kepada guru yang masuk kelas secara sebunyisebunyi kepada 6 guru kelas dan 2 guru mata pelajaran dengan menggunakan lembar pengamatan yang telah dibuat daftar guru yang mengajar di kelas,baik pada saat awal masuk kelas maupun setelah istirahat pertama dan kedua

b. Setelah selesai jam pelajaran, dilakukan rekapitulasi dari hasil pengamatan

c. Kegiatan tersebut dilakukan terus setiap hari kepada setiap guru selama satu bulan (satu siklus).

3. Pengamatan dan Evaluasi

Pengamatan atau observasi dilakukan oleh peneliti dengan menggunakan lembar observasi selama satu bulan (satu siklus), untuk semua guru yang berjumlah 8 orang. Pengamatan oleh peneliti meliputi :

a. Kehadiran guru dikelas

b. Tingkat keterlambatan guru masuk kelas

c. Waktu masuk kelas setelah selesai pergantian pelajaran atau istirahat

Dari hasil pengamatan serta rekap dari tingkat kehadiran guru dikelas pada proses belajar mengajar dapat dilihat pada tabel berikut :

\section{Rekapitulasi Tingkat Keterlambatan guru pda kehadiran di kelas Siklus 1}

Waktu Keterlambatan/Jumlah/ Prosentase

\begin{tabular}{c|c|c}
\hline$<5$ Menit & 5 s.d. 10 Menit & $>10$ Menit \\
\hline 1 & 4 & 3 \\
\hline $12,5 \%$ & $50 \%$ & $37,5 \%$ \\
\hline
\end{tabular}

Dari hasil rekapitulasi tingkat keterlambatan guru dikelas pada proses pembelajaran diperoleh data, sebanyak 1 orang guru terlambat masuk kelas kurang dari 5 menit, 4 orang guru terlambat masuk kelas 5 menit sampai dengan 10 menit, dan 3 orang guru terlambat masuk kelas lebih dari 10 menit. Untuk lebih jelasnya dapat digambarkan pada grafik dibawah ini :

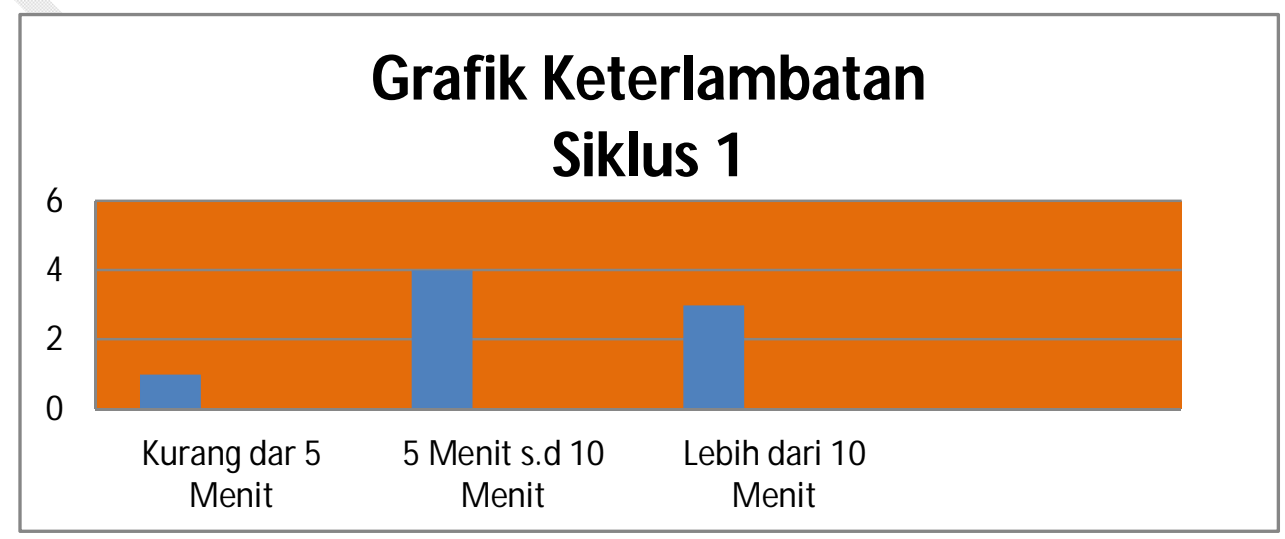


Dari data diatas dapat ditarik kesimpulan bahwa tingkat keterlambatan guru masuk kelas lebih dari 10 menit pada proses kegiatan belajar mengajar masih tinggi yaitu 3 orang atau 37,5\%. Berdasarkan indicator yang telah ditetapkan bahwa keberhasilan tindakan ini adalah $75 \%$, atau bila $75 \%$ guru tidak terlambat kurang dari 10 menit. Pada siklus pertama ini guru yang tidak terlambat lebih dari 5 menit baru $12,5 \%$, jadi peneliti berkesimpulan harus diadakan penelitian atau tindakan lagi pada siklus berikutnya atau siklus kedua.

\section{Refleksi}

Setelah selesai satu siklus maka diadakan refleksi mengenai kelemahan atau kekurangan dari pelaksanaan tindakan pada siklus pertama untuk menentukan tindakan perbaikan pada siklus berikutnya.

Dari hasil refleksi dapat diambil suatu kesimpulan bahwa perlu penerapan Reward dan Punishment yang lebih tegas lagi dari pada siklus pertama.

\section{B. Siklus 2}

Siklus 2 terdiri atas beberapa tahap, sama seperti siklus 1 yaitu : (1) Perencanaan, (2) Pelaksanaan, (3) Pengamatan dan Evaluasi, dan (4) Refleksi.

1. Perencanaan

Dari hasil refleksi pada siklus pertama, peneliti merencanakan untuk melakukan tindakan Reward dan Punishment yang lebih tegas dibandingkan dengan siklus pertama.

Peneliti merencanakan untuk mengumumkan hasil observasi mengenai tingkat keterlambatan guru masuk kelas dalam proses belajar mengajar, pada kegiatan upacara bendera hari Senin. Hal ini terlebih dahulu disosialisasikan kepada semua guru pada saat refleksi siklus pertama.

2. Pelaksanaan

Pelaksanaan penelitian tindakan sekolah pada siklus yang kedua ini dilaksanakan melalui beberapa kegiatan, antara lain :

a. Pada siklus 2 ini,Peneliti menyebarkan lembar pengamatan kepada ketua kelas atau siswa yang dianggap mampu untuk kelas 4,5 dan 6,dan didampingi oleh tenga tidak tetap.Sedangkan kelas 1,2,dan 3,peneliti meminta bantuan kepada staf tata usaha Jumlah lembar pengamatan sesuai dengan banyaknya jumlah rombongan belajar di SD Negeri Aik Kangkung sebanyak 6 rombongan belajar. Dalam lembar pengamatan itu, telah dibuat daftar guru yang mengajar dikelas itu setiap jam dan diberi kolom jam masuk kelas serta jam keluar kelas.

b. Berkoordinasi dengan ketua kelas ,pegawai tidak tetap dan stap tata usaha yang dapat membantu mengedarkan daftar hadir guru dikelas yang telah dibuat agar dapat melihat tingkat kehadiran guru disetiap kelas dan disetiap pergantian jam pelajaran. Guru yang terlambat lebih dari 10 menit, dianggap tidak hadir dan diberi tanda silang. 
Melalui lembar pengamatan, peneliti dan petugas yang ditunjukan melakukan pengamatan atau observasi tentang kehadiran guru secara sembunyi-sembunyi. Pengamatan secara sembunyi-sembunyi ini dimaksudkan agar dapat memperoleh data secara obyektif dan obyek yang diamati tidak merasa sedang diteliti.

c. Setelah selesai jam pelajaran, dilakukan rekapitulasi dari hasil pengamatan, baik dari siswa atau tenaga tidak tetap dan staf tata usaha maupun dari penulis.

Kegiatan tersebut dilakukan terus setiap hari kerja kepada setiap guru selama satu bulan (satu siklus) pada siklus kedua

\section{Pengamatan dan Evaluasi}

Pengamatan atau observasi dilakukan oleh peneliti dengan menggunakan lembar observasi selama satu bulan (satu siklus), untuk semua guru yang berjumlah 8 orang. Selama pengamatan peneliti dibantu atau berkolaborasi dengan ketua kelas bagi kelas 4 s.d.6 dan didampingi oleh pegawai tidak tetap serta stap tata usaha untuk kelas 1 s.d.3.

Pengamatan oleh peneliti meliputi :

a) Kehadiran guru dikelas

b) Tingkat keterlambatan guru masuk kelas

c) Waktu masuk kelas setelah selesai pergantian pelajaran atau istirahat

Dari hasil pengamatan serta rekap dari tingkat kehadiran guru dikelas pada proses belajar mengajar pada siklus kedua dapat dilihat pada tabel berikut :

\section{Rekapitulasi Tingkat Keterlambatan guru kehadiran di kelas Siklus 2}

\begin{tabular}{c|c|c}
\hline \multicolumn{3}{c}{ Waktu Keterlambatan/ Jumlah/ Prosentase } \\
\hline$<5$ Menit & 5 s.d.10 Menit & $>10$ Menit \\
\hline 7 & 1 & 0 \\
\hline $87,5 \%$ & $12,5 \%$ & $0,00 \%$ \\
\hline
\end{tabular}

Dari hasil rekapitulasi tingkat keterlambatan guru dikelas pada proses pembelajaran diperoleh data, sebanyak 7 orang guru terlambat masuk kelas kurang dari 5 menit, 1 orang guru terlambat masuk kelas 5 menit sampai dengan 10 menit, dan tidak ada satu orangpun guru yang terlambat masuk kelas lebih dari 10 menit. Untuk lebih jelasnya, tingkat keterlambatan guru masuk kelas pada proses belajar mengajar pada siklus kedua ini dapat digambarkan pada grafik dibawah ini : 


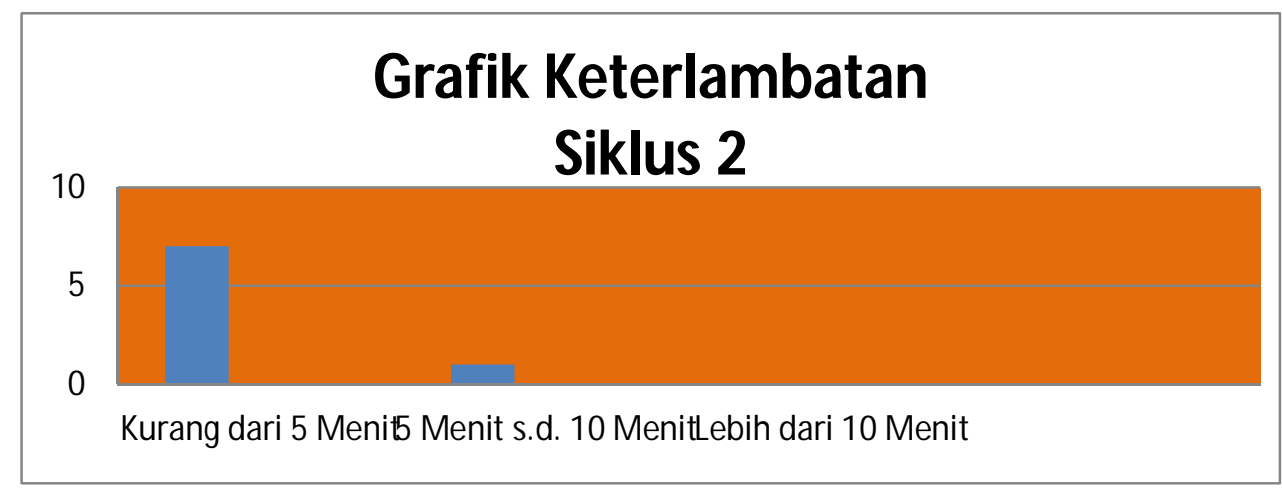

Dari hasil observasi pada siklus pertama dan siklus kedua dapat dilihat ada penurunan tingkat keterlambatan guru dikelas pada kegiatan belajar mengajar, atau terdapat peningkatan kehadiran guru dikelas.

4. Refleksi

bahwa tindakan yang dilaksanakan pada siklus kedua dinyatakan berhasil, karena terdapat 78,26\% guru yang terlambat kurang dari 10 menit, atau melebihi target yang telah ditentukan Setelah selesai pelaksanaan tindakan pada siklus kedua maka diadakan refleksi mengenai kelemahan atau kekurangan dari pelaksanaan tindakan pada siklus kedua tersebut. Dari hasil observasi dan data yang diperoleh, peneliti mengambil kesimpulan sebesar 75\%.

\section{Kesimpulan dan Saran}

\section{A. Kesimpulan}

Berdasarkan analisis data, dari penelitian ini dapat ditarik kesimpulan bahwa penerapan Reward dan Punishment efektif untuk meningkatkan disiplin kehadiran guru dikelas pada kegiatan belajar mengajar. Data yang diperoleh menunjukan bahwa setelah diadakan penerapan tindakan berupa Reward dan Punishment, pada siklus I guru yang terlambat kurng dari 5 menit adalah 1 orang, yang terlambat antara 5-10 menit 4 orang,dan yang lebih dari 10 menit adalah 3 orang,sedangkan pada siklus II guru yang terlambat kurang dari 5 menit adalah 7 orang dan guru yang terlambat anatara 5 - 10 menit sebanyak 1 orang,dan guru yang terlambat masuk lebih dari 10 menit adalah 0. Penerapan Reward dan Punishment dapat meningkatkan disiplin guru hadir didalam kelas pada kegiatan belajar mengajar di SDN Aik Kangkung

\section{B. Saran}

Karena adanya pengaruh positif Penerapan Reward dan Punishment terhadap disiplin guru hadir didalam kelas pada kegiatan belajar mengajar, maka melalui kesempatan ini penulis mengajukan saran : kepada semua guru dalam melaksanakan tugas untuk dapat meningkatkan disiplin dalam kehadiran dikelas sebagai bentuk pelayanan minimal kepada peserta didik disekolah, mengingat kita sebagai guru adalah panutan bagi peserta didik dalam bertutur kata dan kedisiplinan dalam melaksanakan tugas. 


\section{Daftar Rujukan}

Akhmad Sudrajat, (2010) Manfaat Prinsip dan Asas Pengembangan Budaya [On Line].

Tersedia

http:// akhmadsudrajat.wordpress.com/2010/03/ 04/manfaatprinsip-dan-asas-pengembangan-budaya-sekolah/] [06 Oktober 2010]

Amstrong. Michael, (1991). Manajemen Sumber Daya Manusia. Jakrta:Ghalia Indonesia Anwar Prabu Mangkunegara. (1994). Psikologi Perusahaan. Bandung:PT. Trigenda Karya

(2000). Manajemen Sumber Daya Manusia Perusahaan. Bandung : Penerbit Remaja Rosdakarya.

Arikunto, S. (2002). Prosedur Penelitian Suatu Pendekatan Praktek. Jakarta:Rineka Cipta

Aunurrahman. (2009). Belajar dan Pembelajaran. Bandung:Alfabeta

Bambang Nugroho. (2006). Reward dan Punishment. Bulletin CiptaKarya Departemen Pekerjaan Umum Edisi No. 6/ IV/ Juni 2006

Departemen Pendidikan Nasional. (2003). Undang-undang Nomor 20 Tahun 2003 Tentang Sistem Pendidikan Nasional.Jakarta:Depdiknas

Hidayat, Sucherli. (1986). Peningkatan Produktivitas Organisasi dan Pegawai Negeri Sipil: Kasus Indonesia, Jakarta:Prisma

Megawangi, Ratna. (2007). Membangun SDM Indonesia Melalui Pendidikan Holistik Berbasis Karakter. Jakarta:Indonesian Heritage Foundation

Sanjaya, W. (2008). Kurikulum dan Pembelajaran. Teori dan Praktik Pengembangan Kurikulum Tingkat Satuan Pendidikan (KTSP). Jakarta:Kencana Prenada Media Group

Subagio. (2010) Kompetensi Guru dalam Meningkatkan Mutu Pembelajaran [On Line]. Tersedia : subagio.blogspot.com/2010/03/kompetensi-guru-dalammeningkatkan-mutu.html

Syamsul Hadi, (2009). Kepemimpinan Pembelajaran, Makalah Disampaikan pada Sosialisasi Akuntabilitas Kinerja Kepala Sekolah Dalam Inovasi Pembelajaran. Departemen Pendidikan Nasional, Direktorat Jenderal Peningkatan Mutu Pendidik dan Tenaga Kependidikan, Direktorat Tenaga Kependidikan 